\title{
The Reincarnated Campidoglio
}

\author{
Myungshig Kim
}

\begin{abstract}
Architecture and urbanism in everything," "the outside is always an inside" (Le Corbusier, 1929). It implies a possibility of integrating architecture and open urban spatiality as a single concept. Architectural space (building interior) and urban space are related to one another. Architecture is coming out of the making of an interior - a room. Urbanism also begins by making an interior felt as a sense of rapport between building interiors and urban spaces. A street is "a community room by agreement" (Kahn, 1971). It is an urban interior. A square is also an open aesthetic interior by agreement of community. It is the same system of meanings in building interiors as much as "a house is a little city." (Alberti, 1452). This paper explores the destroyed Campidoglio (Rome), the reincarnated genius loci, and the brilliant design of Michelangelo through the documentations. The first site this paper traces is the lost meanings of the Campidoglio. The second site it investigates is the visualizing of the Campidoglio's broken genius loci. The third site it deals with is the contextual rationale between the Campidoglio and the city, Rome. Lastly, this paper presumes the possible principles for the design methods of urban interiors especially in relation to the (re)materializing of the lost genius loci.
\end{abstract}

\section{Keywords—genius loci; urban place and interior design}

\section{REMEMBRANCE OF THINGS PAST AND URBAN PlaCE AS INTERIOR}

At the very beginning of human history, architecture would have been that man had found a fertile land, adapted its topographical conditions and then, visualized its genius loci to settle. The act, materializing of the genius loci is, thus, to help man dwell. Simultaneously, man had kept his life safe, by creating interior, from the severity of external conditions for instance, dangerous animals, fatal weather, and other men. Therefore, architecture fundamentally means to create meaningful place and safe interior, whereby man could dwell and live in. Inhabitancy is the reason for existence of architecture, settlement, and city. To settle in a certain place and to make an interior safe means to provide man with lifeworld "in" the pre-given place and space. Places to mortals are at least limited on the safe interior of the earth that mortals can dwell with things above the floor of earth, and below the ceiling of the sky.

We could not dwell out of the places, and escape from the places, for they are meant to be sheltered for us. ${ }^{1}$ We always

Heidegger, Martin, Poetry, Language, Thought, (Translation with introduction by Albert Hofstadter), New York: Perennial Classics (originally published by Harper \& Row, 1971), 2001, p. 61, Heidegger mentions about emerging, rising and standing on the earth; the buildings rest on the rocky ground and they hold its ground - the earth - against fatal things such as the violence of climate, the danger of beasts, the attack of enemy and so on. "In move "in" the sheltered places which provide us with our life world. It opens itself toward surrounding areas, as a room opens itself to urban/territorial places where a city/country life comes to rise up and where we bring the trajectories of our life to completion. Thereby, the places turn into the internal spaces where we extend inhabitancies. Architecture exists in those spaces: interiors of building, city, country, and earth. A building becomes part of urban/territorial interior and a cluster of buildings shapes urban/territorial interior for the setting of city/country life. ${ }^{2}$ This conception of integrating open urban/territorial interiors and architecture gives a theoretical foundation to the urban interior design and the urban furnishings.

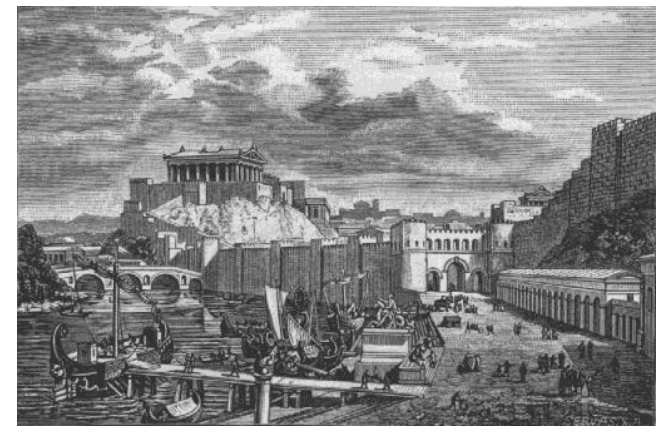

Figure 1. The Tiber river, the temple on the Campidoglio and the fortified city during the Roman Republic 509 BC 27 BC (Friedrich Polack, Geschichtsbilder, 1896).

Long before antiquity, the Campidoglio ${ }^{4}$ (Capitoline hill) was an inhabited settlement where the city legend starts. The hill became a citadel of Ancient Rome (equivalent to the ancient Greek acropolis). In the ancient times, it was changed into a sacred place as much as dedicated to the divinities: the Optimus Maximus Jupiter, Juno and Minerva. The alteration can be seen as an attempt to keep the genius loci of the legendary settlement divine.

the things that arise, earth is present as the sheltering agent." (p. 41) We dwell and live in the sheltering agent. "Upon the earth and in it, historical man grounds his dwelling in the world." (p. 45)

${ }_{2}^{2}$ Zevi, Bruno, Architecture as Space: How to Look at Architecture, New York: Horizon Press, 1957, p. 15.

${ }^{3}$ Ottolini, Gianni, Forma e significato in architettura, Milano: Libreria Clup, 2010, pp. 15-16, also see, Ottolini, Gianni, "Conformazione e attrezzatura dello spazio aperto," Quaderni del Dipartimento di Progettagione dell'Architecttura, n. 4, Milan: Clup, March 1987; Idid., "Urbanistica della luce," in AA.VV., Milano illuminata, Milan: Aem, 1993.

${ }^{4}$ Italian Campidoglio or Capitolino derives from Latin, Capitolium (from Caput, 'head,' the human skull unearthed on the hill) or Capitolinus. Capitol thus derives from Capitolium (Caput). 
The hill was also one of safe urban spaces in the fortified city to evade the barbarians. However, it was gradually devastated by several fatal wars. Its genius loci was also demolished. Finally, it became a secular place of Rome's political life in the later middle Ages. After a few revolutionary events it was left in an untidy conglomeration of dilapidated buildings by Renaissance. ${ }^{5}$ Thanks to Michelangelo, the place was recovered from the untidy, and became a geographical and ceremonial center of the city, which has still served as the symbolic urban place, with reincarnated meanings of the place.

\section{The Lost Genius Loci And UnBeCOMING Place}

The characters of the place had been changed, in turn, from the dwelling, to the sacred, and then to the secular place in Rome's external and political circumstances. In antiquity the hill's dwelling function turned into the sacred place dedicated to the divinities and then, its function was obscured by the movements of urban resistance in the Middle Ages such as the civic government revived as a commune in the $11^{\text {th }}$ century and Cola di Rienzo's revived republic in the $14^{\text {th }}$ century.

A revolt in 1144 was a major event, happened by the citizens against the authority of the Pope. It transformed the sacred Campidoglio into a secular place. It led a senator to take up his official residence on the sacred place. The senator's palace was built in the same year above the ruins of the Tabularium which were buried beneath the place. It was a decisive factor in the direction of the changes; the new palace turned its back on the orientation of the ancient Forum; it destroyed the relationship between the Forum and the piazza of the Campidoglio; after all, it made the piazza isolated. The isolated piazza was laid out in front of the senator's palace, and used for communal purposes such as entertainment, ceremony, trade, even criminal execution, etc. Without the relation to the city, the piazza became an urban internal place surrounded by disordered things (Fig. 2): top: the senator's palace, left: an obelisk, the Santa Maria Church, the stairs, bottom: the mounds of earth, the columns, right: the two separated buildings for trade, and the two Roman river gods. Fig. 2 shows the gradual developments of each building without certain relationships between the buildings and the piazza, and between the place and the city. Fig. 3, 4 and 6 show not merely the disordered situation but also the lost genius loci of the place.

In Fig. 5, it is intriguing that the destroyed, abandoned Forum with the ruins of dilapidated buildings has been left until now in a mess but a beautiful open-outdoor museum, whereas the Campidoglio had been left in the lost meanings of the place by the middle $16^{\text {th }}$ century, when Michelangelo had started to design. Although Michelangelo had reincarnated its meanings as the first precedent design of urban interior, his design had not been completed until 1940.

\footnotetext{
5 The sketch by Van Heemskerck emphasizes that the confusion was accompanied by the formless, unplanned relationship, as it existed when Michelangelo began his work in 1536, among the given conditions.
}

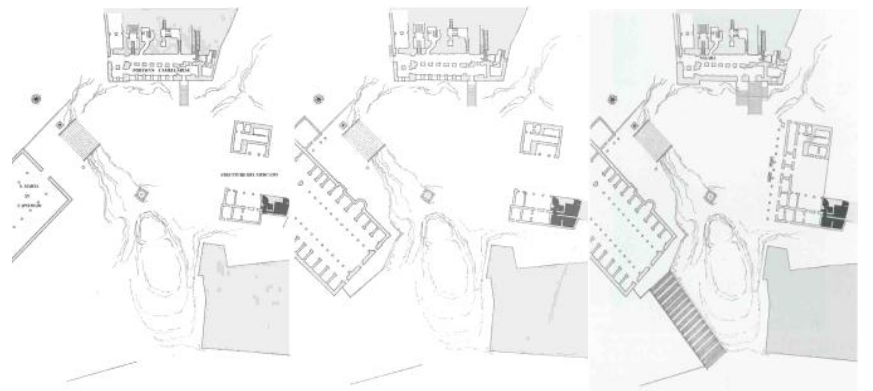

Figure 2. The plans of the Campidoglio, the $13^{\text {th }}$ century (left), 1298 (middle), and 1519 (right).

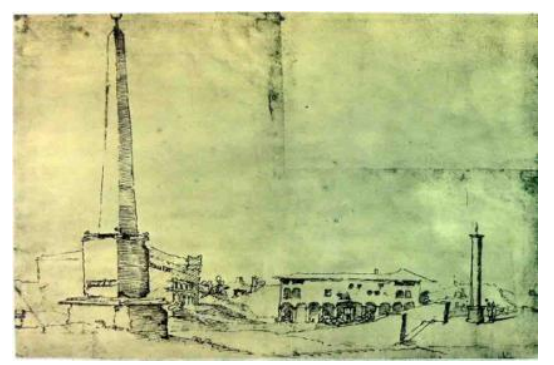

Figure 3. The untidy Campidoglio: the Senator's palace behind the obelisk, the façade of the Conservators' palace, two river's gods in front of the palace, the columns and the mounds of earth, 1536 (Marten van Heemskerck, Kupferstichkabinetti in Berlin).

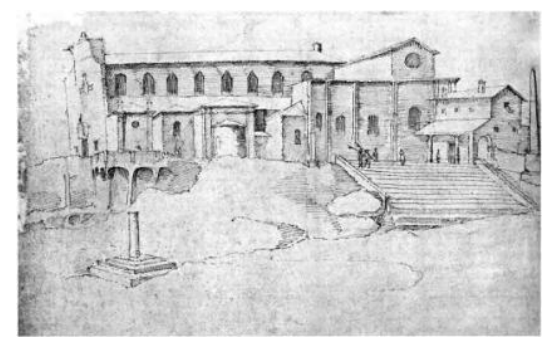

Figure 4. View of the Santa Maria church and the Campidoglio, 1536 (Hülsen-Egger, 1913-16, Staatliche Museum, Bildarchiv Preussischer, Kupferstichkabinett in Berlin).

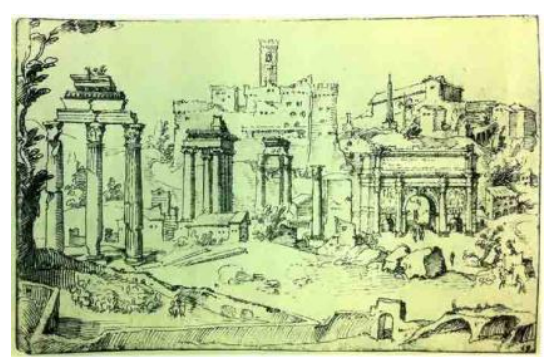

Figure 5. View from the Roman Forum: the Senator's palace (middle), Aracoeli with the obelisk and the palm (right), 1536 (Marten van Heemskerck, Kupferstichkabinett in Berlin).

\section{REMATERIALIZING THE GENIUS LOCI}

Urban design should begin with the character of place and the intention that our spatial existence becomes meaningful among the given environments, the surrounding buildings, and new ones to be added to the place. Hence, the genius loci should be a primary source of all expression with all material 
sources; a work of architecture/urbanism must start by realizing the genius loci, so that the work generates ultimately the value of dwelling: the feelings of well-being and intimacy. To materialize the covered meaning of any place is to transform the place into a meaningful microcosmos of a city as if it is to put a room into a system of a building, the same as the idea that Alberti (1452) calls the house a "little city."

Architecture and urbanism could be considered as a single concept, "architecture in everything, city planning in everything." 6 Dwellings, other buildings, urban places, and urban elements are, thus, related to the same system of meanings; ${ }^{7}$ a city - the gathering of urban places (urban spaces) and buildings (building spaces) - determines a complex but ultimately a cosmic internal structure in its urban interior.

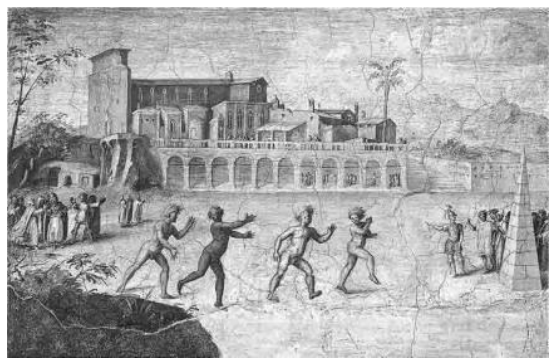

Figure 6. The games of the Romans in the piazza of the Campidoglio, 154647 (the frieze panel in the hall of the Conservators' palace).

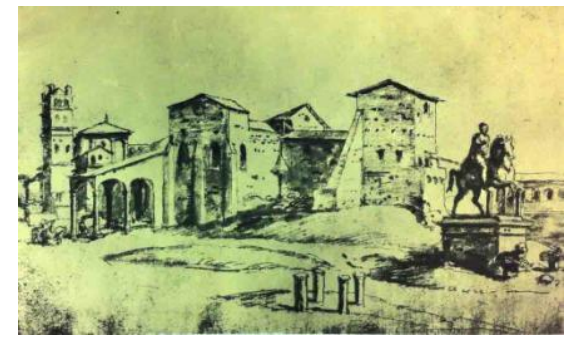

Figure 7. The statue of Marcus Aurelius given by Sisto IV located in the piazza of San Giovanni in Laterano (Marten van Heemskerck, Kupferstichkabinett in Berlin)

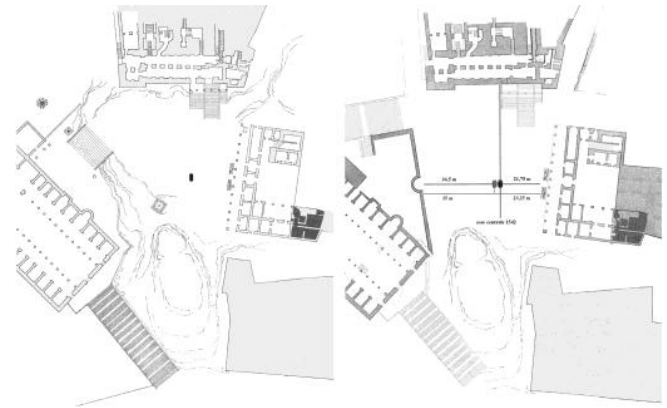

Figure 8. The statue of Marcus Aurelius on the Campidoglio, 1539(left) and the positioning of the statue, 1542(right).

${ }^{6}$ Le Corbusier, "Architecture in Everything, City Planning in Everything," Precisions on the Present State of Architecture and City Planning: With an American Prologue, a Brazilian Corollary Followed by the Temperature of Paris and the Atmosphere of Moscow, (translation by Edith Schreiber Aujame), Cambridge, MA: MIT Press, 1991, p. 68.

${ }^{7}$ Norberg-Schulz, Christian, Meaning in Western Architecture, London and New York: Praeger, 1975, pp. 77ff.
Michelangelo confronted a problem of place design such an urban place especially the disordered, untidy place because he was a sculptor, painter, and architect. Obviously, Michelangelo himself is the first point of the comprehension of what his design shows throughout the entire design phases. He began to visualize the Campidoglio's genius loci by positioning the famous equestrian statue of Marcus Aurelius (Fig. 7) ${ }^{8}$ in the center of the place. What he could think of was a response to the spatial reality, capable of affecting an atmosphere, which some energy can spread out the surroundings from his work. But the most problematic issue to him was how to preserve the characteristics and memory of the place; it must be a matter of anguish between complete preservation and complete redevelopment.

He conceived a matter of maintaining equilibrium which could expose enhancements between the past and successive era of history; the new materializing of place must enhance the forms of the past by "allusion" and by continuity with the aim of producing "a setting more and more densely packed with references to the stream of time rather than a setting that never changed." ${ }^{9}$ It is to give urban place not only the physical continuity of valued places but also the nonphysical continuity of particular character of memory added to the place. It is the zeitgeist of the present accumulated by the past. Such an approach must be what he wanted to express. Thus, to materialize genius loci and memory obviously benefits dwelling in the urban contexts, that is, our life-world.

Michelangelo sought a departure of the design in the necessity of order from the formless irregular topography, the disorganized place, and the old crumbling buildings. Fig. 8 shows the first attempt to reconstruct the broken genius loci by positioning the statue of Marcus Aurelius in the given, unplanned environments in order to present "the degree of imagination necessary to conceive order that eventually would arise." $" 10$

He placed the equestrian statue in the center, and positioned it in the direction to the Basilica of St. Perter (Fig. 17). It was the very beginning of the design by a single act of will, considered as an induction of order and also concerned with the linking of the city. It seems that energy can spread out the surroundings (Fig. 18). ${ }^{11}$ The central point of the statue was 'a thing' gathering things (Heidegger, Das ding, 1950) that pulled chaos into order and simultaneously set up the axis passing through the center and the Palazzo Senatorio (senator's palace). ${ }^{12}$ Both a point and a line were in effect primary

${ }^{8}$ The statue was only a monumental bronze of antiquity in 1536 . It was located in Laterano ( $2 \mathrm{~km}$ away), the Piazza of San Giovanni. Its determination by the Pope, Paul III was the first starting point of the place design for the untidy place. But Michelangelo disagreed the moving of the Marcus Aurelius' statue because he thought it was not suitable for the place.

${ }^{9}$ Lynch, Kevin A., What Time is This Place?, Cambridge, MA: MIT Press, 1972 , p. 236.

${ }^{10}$ Bacon, Edmund, Design of Cities, London: Thames and Hudson, 1967, pp. $100-105$.

${ }^{11}$ Michelangelo could treat the nicest graduations in plane with the same unerring sureness, for Michelangelo confidently handled such unprecedented voids as the dome of St. Peter's. See, Giedion, 1982, p. 68.

${ }^{12}$ Bacon (1967) insists the line. However, a point is rather much more important, for the most precise interpretation to the design can be extracted from order which the statue produces tensions: radiation, absorption, and 
principles of the place design to organize the unpleasing elements. He gradually extended the order into the surroundings. It implies that from the beginning he conceived a plan for the site, as a whole like "harmony takes its origins from afar, everywhere, in everything." 13 He visualized the hidden meaning of the Campidoglio and materialized the treasures of the place with the conception of place design concerned with our spatial existence in a totality like a man in a room.

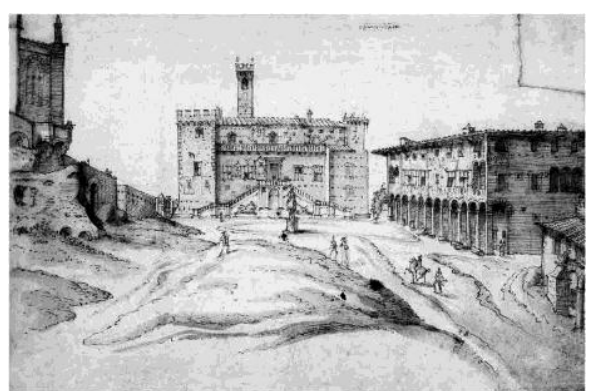

Figure 9. View of the Campidoglio, 1555 (anonymous, Ecole d'Itaie, INV $11028 \mathrm{r}$ in Louvre Museum).

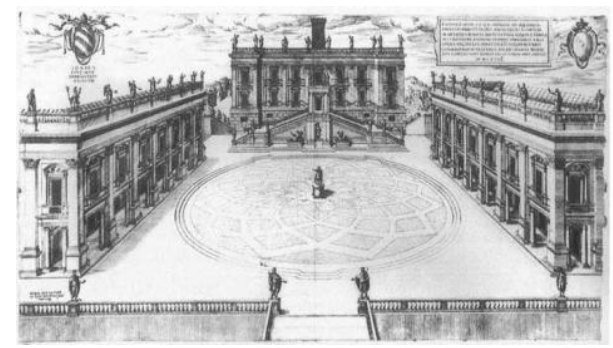

Figure 10. The Campidoglio (Stefano Du Pérac, etching, 1568).

Michelangelo secondly gave the triangular stairs (Fig. 9), instead of the old three stairs, to the façade of the senator's palace: a fountain to the center of the stairs: the two rivers' gods, the Tiber and the Nile to both sides of the fountain: lastly the campanile (Fig. 10) to the center of the palace. This design is based on the axis of the statue which crosses over the Campidoglio. The axis and the statue of facing St. Peter's Basilica lead to a grand Cordonata ${ }^{14}$ contacting with the city below to bring an order of the axis to completion. In addition, the axis has an effect on the internal spaces of the palace (Fig. 11): the courtroom, the steps leading to next rooms, and further inner rooms. It is a mode, in extent, of power that the statue creates the feeling of order and "the larger order is irreversibly set in motion.",15

extension. Therefore, the first capture should be a point of the equestrian stature of Marcus Aurelius in the entire plan rather than its axis. The point is a thing alive by dynamic force as the origination of the design: a statue on the oval pedestal: in the center of the oval pavement: within the trapezoidal piazza: surrounded by the colossal Corinthian façades of the surrounding palaces: started with gradual internal spaces: radiating their interiors out toward city: with Cordonata linking the city. This is what the Campidoglio presents the 'order' of the centrifugal.

${ }^{13}$ Le Corbusier, "Precisions on the Present State of Architecture and City Planning..., 1991, p. 77.

${ }^{14}$ A sloping road (similar to a flight of steps), composed of transversal stripes made with basalt.

${ }^{15}$ Bacon, Design of Cities..., 1967, p. 103.

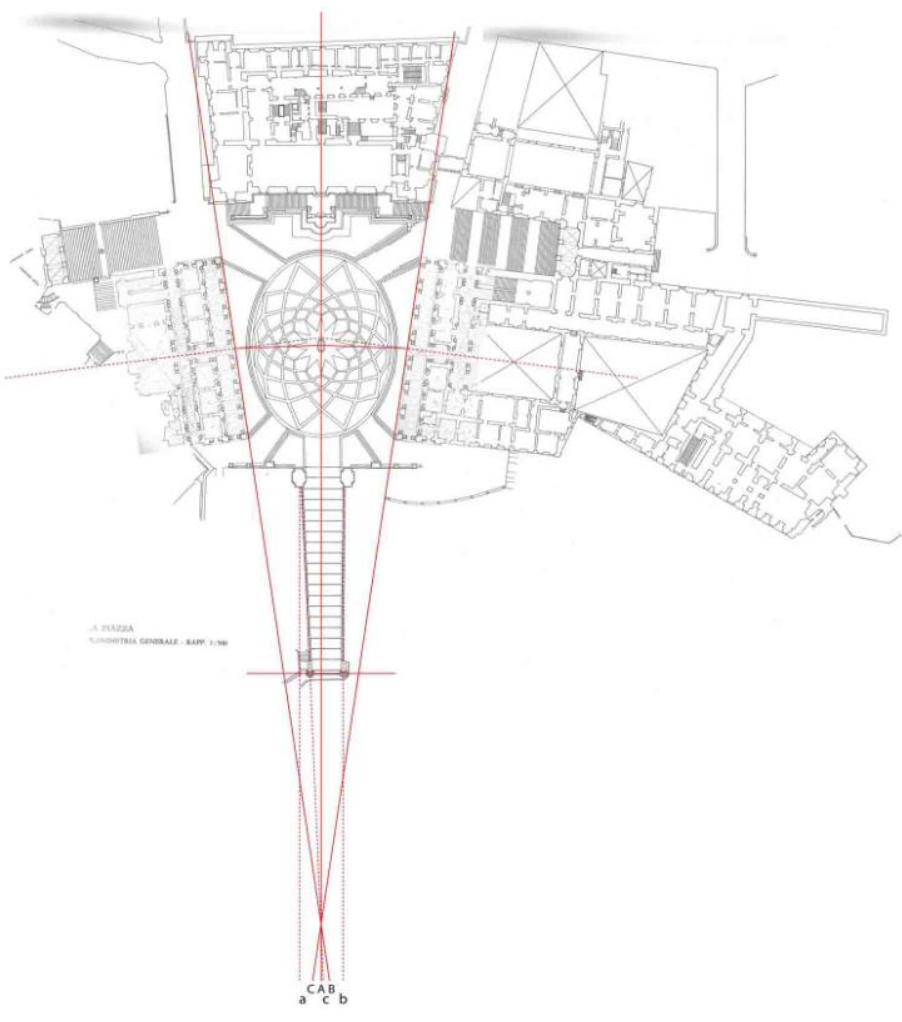

Figure 11. The axes, A: the main axis, B and C: the diagonal angle in symmetry, $\mathrm{a}$ and $\mathrm{b}$ : the parallel balustrades of the Cordonata, $\mathrm{a}$ and $\mathrm{c}$ : the compromising steps between the steps of Santa Maria church and the Cordonata.

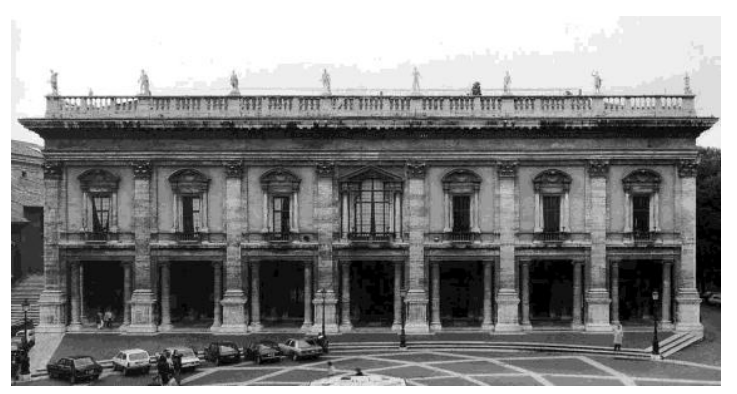

Figure 12. The façade of the Conservators' palace.

Thirdly, Michelangelo planed the Palazzo dei Conservatori (Conservators' palace) and the Palazzo Nuovo (New palace) to be positioned in symmetry. He renovated the old colonnade for the façade of the Conservators' palace and the transitional space between the piazza and the palace. Based on his interpretation through the past aesthetics, he incorporated the giant Corinthian pilasters and the subsidiary Ionic columns of the façade (Fig. 12). He also designed a contrast of light, a variety of shadow effects, the transitional colonnade space, the contrast of the windows and the plain surface, etc. Thus, the façade produces not only the effect, absorbing the centrifugal force of the statue via the star-shaped pattern of the oval but also the innumerable effects of "chiaroscuro.', 16

16 Schiavo, Armando, Michelangelo Architetto: Michaelangelo as an Architect, Miguel Angel Arquitecto, Roma: La Libreria Dello Stato, 1949. 


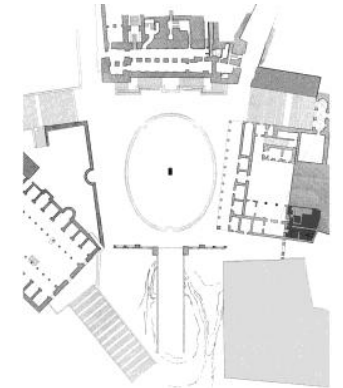

Figure 13. The plan of the Campidoglio, 1561.

The first step for the plan of the New palace was to simply cover up the irregular buildings in Aracoeli (left in Fig. 13). ${ }^{17}$ It became the New palace in perfect symmetry with the Conservators' palace later on. This palace was the most novel and exciting aspect of Michelangelo's design; its façade and internal spaces were duplicated to that of the Conservators' ones, except the niche for Marforio. Its function was purely aesthetic in order to harmonize the place based on the order the point and the axis; thereby two wing axes generate on both sides (Fig. 11).

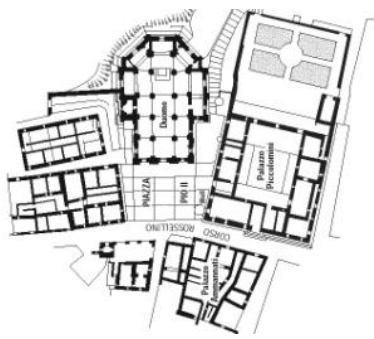

Figure 14. The piazza Pio II, Pienza, 1459 (Bernardo Rossellino).

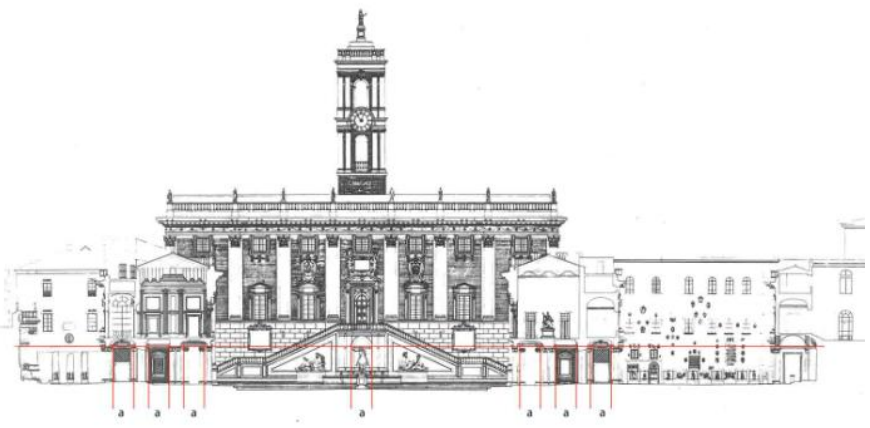

Figure 15. The same measurements by the statue of Marcus Aurelius.

The two symmetrical buildings make the piazza peculiarly trapezoidal, equivalent to the Piazza Pio II in Pienza (1459), ${ }^{18}$

\footnotetext{
${ }^{17}$ The first design only shows the wall with a niche, now occupied by a statue of Marforio on an axis of wing, to cover the church of the Aracoeli. The palace was constructed in 1603 , finished in 1656 , and opened to the public in 1734.

${ }^{18}$ The Piazza Pio II was inspired by a work of Leon Battista Alberti, Palazzo Rucellai in Florence. The Campidoglio may be, as Tolnay's interpretation, a link between the early Renaissance expressions of urban design in Florence and the great Baroque developments in Rome. Because, according to Tolnay (1981), the architecture of the Tuscan Renaissance had tended towards symmetrical piazzas since the fifteenth century such as the Piazza Pio II.
}

which gives observers conscious perspectives depending on the distance of the main building. There is no any note discovered which records Michelangelo's visit to Pienza; He might have visited or known, before the period of the Campidoglio's design. Michelangelo applied this effect more strictly as nearly perfect as possible not to be approximate.

The two symmetrical palaces and their rooms, as mentioned above, absorb the force of the statue. The statue defines all of the Campidoglio (Fig. 15): the ceiling height of the ground floor concerned with the statue's height: the bay depth capable of embracing the statue: the further inner rooms compartmented by the same bay. The spaces are rhythmically composed from the statue into: open (piazza), transitional (loggia), closed (room), transitional (loggia), open (the courtyards of both the symmetrical palaces). Beyond the Conservators' palace, there are the inner spaces in the Caffarelli Clementino's palace now serving as an annex to its palace which has an intriguing courtyard Aymonino proposed Michelangelo's oval. ${ }^{19}$

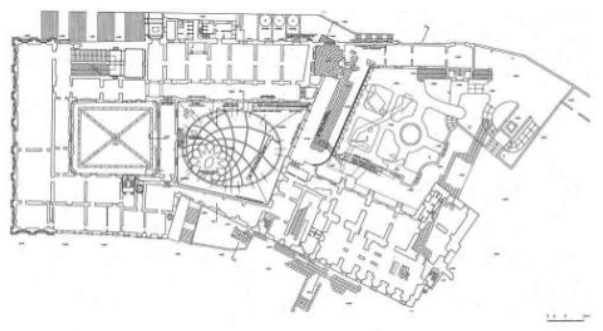

Figure 16. The plan of the courtyard in the Caffarelli Clementino's palace, 1993 (Carlo Aymonino).

Michelangelo designed, lastly, two balustrades to the front, narrow side of the trapezoidal piazza (Fig. 10 and 11). The two balustrades guide a magnificent stair, Cordonata of the extended central axis which leads up to the interior of the piazza from the city below. It features the wide breadth for horse riders to ascend the hill without dismounting and the stepped ramp like a slow-moving escalator to deposit them on the threshold of municipal authority and to lift its visitors toward the very urban interior and vice versa. ${ }^{20}$ It accentuates the central axis leading toward the city and the center of the Basilica of St. Peter (Fig. 17). The design is thus a decisive piece of urban planning between the Campidoglio and the city. Thereby the Campidoglio was complete, as an urban interior.

Michelangelo connected the place to the city as the last part of order but as a firm delineation. It draws the inner order of the piazza to the external urban places. The sequence of the axis - city, Cordonata, piazza, and central palace - was the first urban introduction of the 'cult of the axis' (le culte de l'axe) which was used for Italian piazza plans, and which became "the vertebrate principle of the eighteenth-century town planning in France.",21

\footnotetext{
${ }^{19}$ Aymonino, Carlo, Hanssen, Genevieve, and Pitzalis, Efisio, Il Campidoglio di Carlo Aymonino, Milano: Federico Motta Editore, 2000.

${ }^{20}$ Morgan, Charles H. The Life of Michelangelo. New York: Reynal and Company, 1966, pp. 209-211.

${ }^{21}$ Giedion, Sigfried, Space, Time and Architecture, Cambridge MA: Harvard University Press, 1982, p. 70.
} 


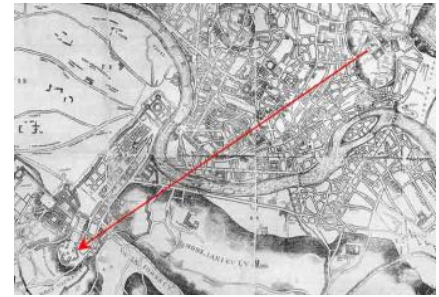

Figure 17. The direction of the Compidoglio on the map of Rome, 1551 (I. Leonardo Bufalini).

\section{WAY INTO THE CITY, URBAN INTERIOR}

Michelangelo obviously conceived the Campidoglio as an open space - an urban interior - surrounded on all sides. Then, he could employ his previous design languages such as the ideas of "interior architecture." 22 The floor pattern in the Laurentian library (Fig. 18, e) is an example; a central point spreads out and defines the surrounding. It is the same as an equestrian statue of Marcus Aurelius, which gives an order to the Campidoglio and thus, defines the surroundings. Its dynamic force gives the particular atmosphere to the place; a living energy creates order, gathers things, and shapes an interior. The idea was a departure to transform the assortment of the diffused parts into an ensemble and a strongly unified piazza. It is also to materialize the genius loci, that is, caput mundi represented by the convex oval as terrestrial globe (Fig. 18 , f and 19) - a settlement where the city's history started. Under the centrifugal point, the other statues of ancient divinities are placed on all the balustrades of the Campidoglio to recover the sacred function as if those inhabit in a higher sphere and celestial world (Fig. 12 and 15).

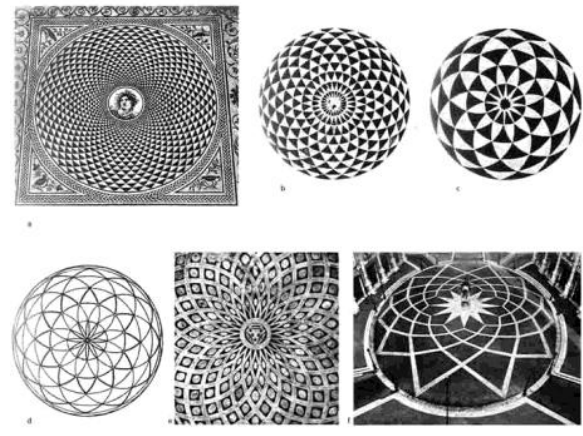

Figure 18. Designs for pavements. a, the mosaic of Roman floor about A.D. 100, Rome, Museo Nazionale. b, the floor of the Florence Baptistery about

1225. c, a marble intarsia, dated 1157, Faltona, S. Felicità, d, ornamental rosette for parquetry, woodcut by Dürer, published 1525. e and f designed by

Michelangelo. e, the pavement in the Biblioteca Laurenziana, designed in

1524. $f$, the ornamental pavement of the Piazza of the Campidoglio, designed in 1546 and realized in 1940 .

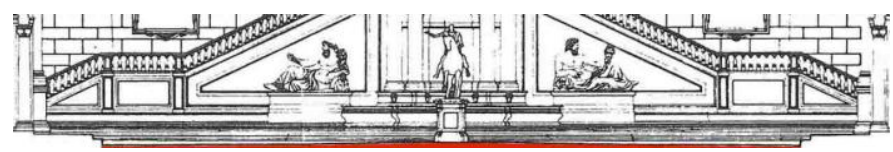

Figure 19. The statue of Marcus Aurelius and the oval pedestal on the top of the covex (swelled-up) oval ground.

\footnotetext{
${ }^{22}$ Tolnay, Charles de, Michelangelo: Sculptor, Painter, Architect, Princeton: Princeton University Press, 1981, p. 158.
}

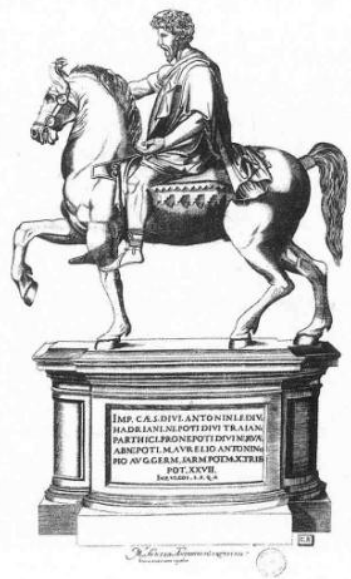

Figure 20. The statue of Marcus Aurelius on the oval pedestal, 1548 (Nicolas Béatrizet, engraving, 1565).

Michelangelo would have used a compass, invented for inscribing ovals, to unite the irregular buildings, to represent the genius loci, and to encompass the surroundings; the outline of the convex oval is in line with the oval pedestal (Fig. 20). The oval pedestal is lower than a pedestal for the Tomb of Lorenzo de' Medici in Medici Chapel in Florence (1520-24) which Michelangelo already designed low in order to express a magnificent sense of the statue. He designed the lower oval pedestal for the same effect and then, made the oval shape of the piazza swell up. It swells gently upward the oval pedestal. It recalls the old idea, caput mundi as if "the oval is likened to the earth." ${ }^{23}$ Furthermore, it is decorated with a pattern of interlaced and twelve-pointed star, which represents an ancient cosmological scheme - constellations revolving around this place (Fig. 18). ${ }^{24}$

The point of the statue and the pattern are, thus, considered in terms of 'rootedness' - "to have roots in a place is to have a secure point from which to look out on the world, a firm grasp of one's own position in the order of things, and a significant spiritual and psychological attachment to somewhere in particular." ${ }^{25}$ When one stands on the oval, he can sense himself standing on the exposed segment of the terrestrial globe, at the center of the city, and at the center of the world as if a thing is the unity as sum and totality; the aistheton ${ }^{26}$ gathers what things are.

Unfortunately, the pattern had never been executed under the popes who may have detected its subtext better than Christian import. The original pattern was replaced with the pattern of stripes instead. It was used to decorate the piazzas of Italian major cities for instance, the semi-rounded piazza at Siena in the fourteenth century (1349).

${ }^{23}$ Tolnay, Charles de, "Beiträge zu den späten architektonischen Projekten Michelangelos,” Jahrbuch der Preussischen Kunstsammlun, vol. 51 (1930), p. 26. This statement may be compared with H. Sedlmayr's prompt attack on it which will be found on pages 176-181 of the same publication for 1931 .

${ }^{24}$ However, it had been realized under Benito Mussolini (1940); its realization took four centuries.

${ }^{25}$ Relph, Edward, Place and Placelessness, London: Pion, 1976, p. 38.

${ }^{26}$ Aistheton (Greek) used by Plato is to indicate the visible aspect of the primeval cause of the manifested world which is sensible, perceived by the senses in contrast with Noeton (intelligible). 


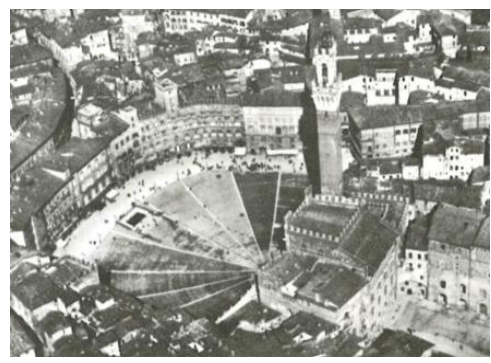

Figure 21. Aerial view of the Piazza del Campo in Siena.

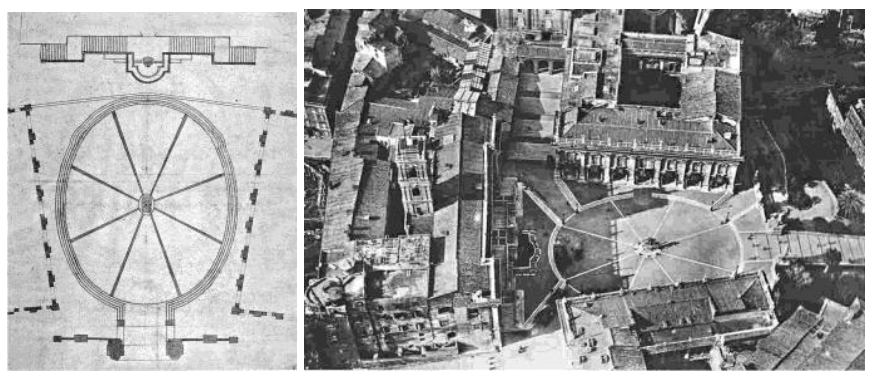

Figure 22. The plan of the pavement, 1659 (Carlo Rainaldi, BAV, cod. Chig. P.VII 10, cc. 92v-93r.) and aerial view of the Campidoglio, 1922.

In short, the Campidoglio was designed by inducing orders, measuring the surroundings, and setting the relationships among the statue (pivot), the Piazza's pattern (direction of tension), the façades of the Palaces (plane); these are the design methods for "piazza-salone" (open-air room), called in Italy (Fig. 23). Thus, its design is based on order, the mathematically calculated central pivot and the gradually extending axes from the center to the peripheral, as energy extends like a centrifugal force. It extends the axes to the surroundings: the Palaces, their internal spaces, and Rome's atmosphere. This urban place opens, in a sense of the order-extension, all the regions of Rome in which "it gathers things in their belonging together.",

\section{CONCLUSION}

Michelangelo saw through the concept of place which cannot be captured in the sense of the unit but in the sense of the unity as a whole of form which gathers things and consists of things we perceive. In this respect, the Compidoglio was designed with the certain relations between things: the equestrian statue as an origination of order, the fantastic pattern spreading out, the two travertine steps of the oval slightly recessed and ringed around, the trapezoidal piazza, the subtly shifting interplay of light and shadow on the Palaces's façades, the four openings accessible from the city, the grandiose gesture of the Cordonata linking with the city, and the gradual deployment of the Palaces's rooms.

The order-extension and centrality define all parts of the Campidoglio, as Geoffrey quotes Giedion's words: "all combine to form a single all-embracing harmony, for the relation of each to each and of the whole to its parts has been consummately affined." 28 The single all-embracing harmony made the Campidoglio brilliant. It is indeed an impressive, precedent case of urban interior.

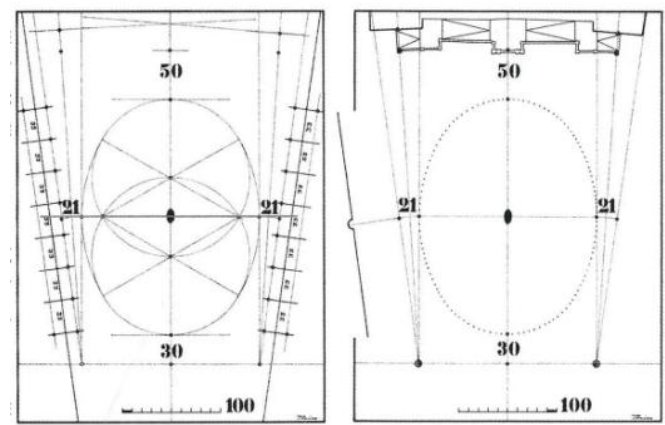

Figure 23. The central point of the piazza of the Campidoglio and the major axes, 1980 (Thies).

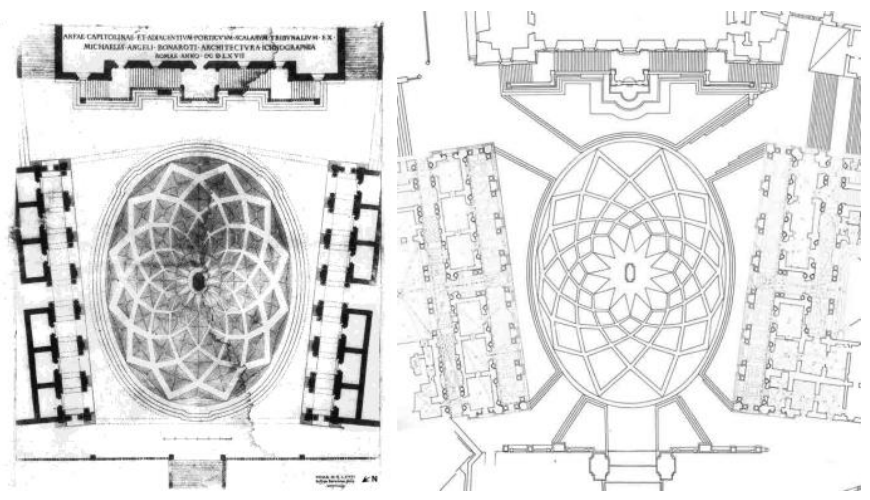

Figure 24. The plan of the Campidoglio, 1557 (anonymous, engraving, ed Bartolomeo Faleti, “Areae Capitolinae Et Adiacentium Porticuum Scalarum

Tribunalium Ex / Michalis Angeli Bonaroti Architectura Ichnographia / Romae Anno MDLVII" and the plan of the Campidoglio, 1940

The urban interior, Campidoglio was finally completed with the twelve-pointed star pattern of the oval Piazza in 1940. Michelangelo's last detail was done, materialized, and delivered. No particle of the ground was left unconsidered. Many people have visited the urban room to experience the single-embracing harmony completed from a statue to the city. The harmony is "gathering," by the induction of order and a conscious aggregate of references to the meanings of the place: the caput, a settlement, the glorious Roman history, the sacred atmosphere, ancient, and modern. ${ }^{29}$ The rematerialized place of the Campidoglio's genius loci discloses an intimate yet monumental grandeur and a unity of diverse parts. Thus, the Campidoglio is not the design as a piece of urban planning but rather urban design itself.

The Campidolgio is the best materialized place of holy mood, emotional resonance, and impressive urban interior, as city planning ever built. It appears as an enclosed, protected piazza, an open-closed interior, or a giant outdoor room open to

\footnotetext{
${ }^{27}$ Heidegger, Martin, Die Kunst und der Raum, (Art and Space, translation by Charles H. Seibert), Erker Verlag: St. Gallen, 1969, p. 10.
} 
the sky and accessible from the city. ${ }^{30}$ It is not merely a crucial precedent for urban place and urban interior design, but also what the brilliant design shows for the successive ear (Fig. 24). The inducing orders, the order-extensions, central rootedness of relationships are, therefore, the possible principles as the design methods of modern urban interiors especially with reference to the (re)materializing of the lost genius loci.

\section{REFERENCES}

[1] Aymonino, Carlo, Genevieve Hanssen, and Efisio Pitzalis, Il Campidoglio di Carlo Aymonino, Milano: Federico Motta Editore, 2000.

[2] Bacon, Edmund, Design of Cities, London: Thames and Hudson, 1967.

[3] Bedon, Anna, Il Campidoglio, Storia di un monumento civile nella Roma papale, Milano: Electa, 2008.

[4] Broadbent, Geoffrey, Emerging Concepts in Urban Space Design, New York: Taylor \& Francis, 2005

[5] De Angelis d'Ossat, Guglielmo, Carlo Pietrangeli, Enrico Del Debbio, Giuseppe Perugini, and Leonard von Matt, Il Campidoglio di Michelangelo, Milano: Silvana, 1965.

[6] Giedion, Sigfried, Space, Time and Architecture, Cambridge MA: Harvard University Press, 1982.

[7] Heidegger, Martin, Poetry, Language, Thought, (translation with introduction by Albert Hofstadter), New York: Perennial Classics (originally published by Harper \& Row, 1971), 2001.

[8] Hibbard, Howard, Michelangelo, New York: Harper \& Row, 1974.

[9] Le Corbusier, Precisions on the Present State of Architecture and City Planning: With an American Prologue, a Brazilian Corollary Followed by the Temperature of Paris and the Atmosphere of Moscow, (translation by Edith Schreiber Aujame), Cambridge, MA: MIT Press, 1991.

[10] Lynch, Kevin A., What Time is This Place?, Cambridge, MA: MIT Press, 1972.

[11] Morgan, Charles H. The Life of Michelangelo, New York: Reynal and Company, 1966.

[12] Norberg-Schulz, Christian, Meaning in Western Architecture, London and New York: Praeger, 1975.

[13] Ottolini, Gianni, 'Conformazione e attrezzatura dello spazio aperto,' Quaderni del Dipartimento di Progettagione dell'Architecttura, n. 4 (March 1987): 38-50.

[14] , Forma e significato in architettura, Milano: Cortina, 2012.

[15] Relph, Edward, Place and Placelessness, London: Pion, 1976.

[16] Schiavo, Armando, Michelangelo Architetto: Michaelangelo as an Architect, Miguel Angel Arquitecto, Roma: La Libreria Dello Stato, 1949.

[17] Tolnay, Charles de, Michelangelo: Sculptor, Painter, Architect, Princeton: Princeton University Press, 1981.

[18] C 'Beiträge zu den späten architektonischen Projekten Michelangelos,' Jahrbuch der Preussischen Kunstsammlun, vol. 51 (1930): 26.

[19] Wallace, William, Michelangelo: The Artist, the Man, and His Times, Cambridge: Cambridge University Press, 2010.

[20] Zevi, Bruno, Architecture as Space: How to Look at Architecture, New York: Horizon Press, 1957.

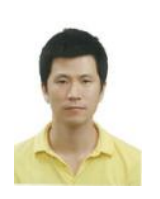

Myungshig Kim holds a Ph.D. degree in Interior Architecture and Design. The theory of interior is the main subject of his own research and his work is revolved around the theoretical thinking of interiors that a society of rooms and a society of urban/territorial rooms consist of our life-world.

\footnotetext{
${ }^{30}$ Wallace, William, Michelangelo: The Artist, the Man, and His Times. Cambridge: Cambridge University Press. 2010, pp. 229-232.
} 